\title{
A Community-based Educational Program on Breastfeeding in Indramayu, West Java, Indonesia
}

Sujana Jatiputra

\begin{abstract}
Abstrak
Penyuluhan tentang menyusui bayi pada tahun 1990 di kecamatan Gabus Wetan, Indranayu, Jawa Barat yang diintegrasikan dengan kegiatan pembangunan lain oleh tenaga penyuluh yang telah mendapat pelatihan. Subyek penelitian adalah ibu-ibu yang melahirkan hidup dalam tiga tahun terakhir dan tinggal di Gabus Wetan. Hasil analisis 778 subyek yang terdiri 242 yang mengikuti penyuluhan dan 536 yang tidak mengikuti penyuluhan menunjukkan ibu-ibu yang mengikuti penyuluhan berumur lebih muda dan berpendidikan lebih tinggi (masing-masing dengan nilai P sebesar 0.04 dan 0.05). Setelah dikontrol terhadap umur, lebih banyak ibu di kelompok yang turut penyuluhan yang tahu tentang menyusui bayi daripada kelompok yang tidak turut penyuluhan mengenai kapan mulai menyusui dengan tepat (Risiko Relatif Mantel-Haenszel $=R R_{\mathrm{mh}} 4.59,95 \%$ CI 3.81-5.54), kolostrum penting untuk bayi $\left(R R_{\mathrm{mh}} 1.52\right.$, $95 \%$ CI 1.42-1.62) dan kapan mulai dengan benar memberi makanan tambahan kepada bayi $\left(R R_{\mathrm{mh}} 6.62-8.30\right)$. Sedangkan pengontrolan terhadap pendidikan menghasilkan masing-masing $R R_{\mathrm{mh}}$ dan $95 \%$ CI 4.62 (3.83-5.56), 1.52 (95\% CI 1.43-1.63) dan 6.28 (95\% $0.05-7.82$ ).
\end{abstract}

\begin{abstract}
As part of a series of studies, an evaluation of the perception of women regarding Information, Education, and Communication (IE\&C) on breastfeeding was undertaken in 1990. It was conducted by mid-wives, family planning workers, cadres, traditional birth attendants, village officials, and previously trained IE\&C personnel of Animal Husbandry and Agriculture. The subjects were women living in the subdistrict of Gabus Wetan, Indramayu, West Java, with live births in the last three years. Out of the 791 women meeting the criteria, 243 attended the IE\&C program (IE\&C group), while 548 did not attend (nonIE\&C group). For the final analysis, 778 were eligible, with 242 in the IE\&C group and 536 in the nonIE\&C group. The IE\&C group was found to be slightly younger in age $(P=0.04)$ with a higher level of education $(P=0.05)$. More women in the IE\&C group knew when to initiate breastfeeding $\left(R R_{\mathrm{mh}} 1.52\right.$, $95 \%$ CI 3.81-5.54), the importance of colostrum $\left(R R_{\mathrm{mh}} 1.52,95 \% C I 1.42-1.62\right)$, and when to start supplementary feeding (RR $R_{\mathrm{mh}}$ $6.62-8.30$ ). When adjusted to the educational level, $R R_{\mathrm{mh}}$ and $95 \%$ CI of $4.62(3.83-5.56)$, were 1.52 (95\% CI 1.43-1.63) and 6.28 (95\% CI 5.05-7.82) respectively.
\end{abstract}

Keywords : Breastfeeding, perception, IE\&C

\section{INTRODUCTION}

Human milk is the food of choice for infants, especially during the first few months. It contains the proper nutrition needed for the infant and substances for protection against infections, besides the added psychological benefits of breastfeeding. Recently it was discovered, that breastfeeding can also act as a method of contraception. In a booklet released by the World Health Organization for Health Workers, it was stated that the effectiveness of breastfeeding in preventing pregnancy at six months postpartum is up to $98 \%$. This depended on whether the mother is still amenorrhoeic at that time, is frequently breastfeeding on demand over a 24-hour period, and does not provide supplementary feeding to the infant. ${ }^{1}$

Most of the female population in Indonesia (95 $98 \%$ ) breastfeed their infants. The proportion is slightly lower in the urban areas. ${ }^{2}$ In Jakarta, about $98 \%$ initiate breastfeeding. ${ }^{3}$

On the average, Indonesian women breastfeed their infants for about 19.8 months. ${ }^{3}$ A recent data revealed that in the urban areas, the average duration is 17.3 months, while in the rural areas, it was 23.1 
months. ${ }^{4}$ In addition, there is also a widespread use of prelacteal food or fluids with an early introduction to supplementary food. These problems have also been identified in the Indramayu district.

This paper will discuss the perception of the women of the Gabus Wetan subdistrict on the subject of breastfeeding, in relation to the Information, Education, and Communication Program (IE\&C).

\section{METHODS}

This study is part of a series of studies conducted by the project breast feeding and family planning in the subdistrict of Gabus Wetan, Indramayu. It involves the evaluation of the perception of the women of this subdistrict to breastfeeding and family planning.

The IE\&C project consists of 3 stages. In the first two stages, IE\&C personnel at the subdistrict and village levels were trained. In the third stage, the newly trained personnel conducted a community-based educational program to the target women. The IE\&C sessions were voluntarily attended by the women (nonradomized). Ten villages in the subdistrict of Gabus Wetan, Indramayu, West Java were chosen. Women having live births within the last 3 years were included in this study.

In February 1990, workers from Health, Family Planning, and other related sectors, such as Agriculture, Education and Culture, Community Development, etc., were recruited and trained for 3 days as IE\&C personnel. Traditional birth attendants (TBA) were given separate training lasting 2 days.

IE\&C materials were produced as booklets for physicians, nurse and midwives (NMW), and family planning workers, as counseling flipbooks for all health providers and outreach workers, as posters for clients, and as taped messages especially designed for a specific target audience. ${ }^{5}$

The IE\&C on breastfeeding and family planning was begun on March 1990. It was integrated with other development programs in the various sectors. Data on the perception in breastfeeding and family planning were collected from April to June 1990.

The topics covered in the training were in line with problems identified earlier. They were: (1) the benefits of breastfeeding, (2) managing breastfeeding, (3) the problems of breastfeeding, (4) suitable contraceptives for breastfeeding women, (5) supplementary feeding, (6) nutrition in babies, pregnant, and lactating women, and (7) how to counsel, prepare, and conduct IE\&C sessions. ${ }^{6}$

The messages to be put across in the IE\&C sessions were: (1) to start with breastfeeding immediately, (2) not to give any food or drink before breast- feeding, (3) to give colostrum, and (4) to start supplementary feeding after 4 months.

Baseline data were collected from October to December of 1989 by trained interviewers experienced in conducting interviews using simple structured questionnaires.

The questionnaire consisted of 6 questions on prelacteal, breastfeeding, and supplementary food. They were: (1) when should you initiate breastfeeding, (2) is the first flow of milk important, (3) is the first flow of milk harmful to the baby, (4) should honey or syrup be given before initiating breastfeeding, (5) when should you start to give supplementary food, and (6) what kinds of supplementary food should you give.

There were eight answers to the first question, ranging from immediately after birth to when the baby is a day old. Score 1 was given if the answer was immediately after birth, and 2 if the answer was other than the correct answer. The answer to the second, third, and fourth questions is either yes or no. The fifth question has 4 answers, ranging from after the baby is 1 week old to after 4 months. score 1 was given if the answer is after the baby is 4 months old and 2 if the answer is incorrect. The sixth question had 4 answers, bananas, soft steamed rice, rice porridge, and others.

There were 791 women in this study, with 243 attending (IE\&C group) and 548 not attending (non IE\&C) the IE\&C. Those women with any missing data, 1 attending and 12 nonattending, were excluded from the final analysis, making the total 778 .

The data were analyzed by computing the crude relative risks (between IE\&C exposed and nonexposed) and the Mantel-Haenszel adjusted rates for age and education with a $95 \%$ confidence interval.

\section{RESULTS}

\section{Subject characteristics}

The characteristics of the subject in the study, such as education, age, occupation, marital status, type of contraceptive used, and number of living children, are presented in table 1 . The 2 groups were similar in characteristics, except for education and age which differed statistically. Education was classified as no schooling, low for those that have attended any type of primary school, and high for those that have at least attended junior high school. No subject had an education higher than high school. The women in the IE\&C group tend to have a higher level of education. The difference was statistically significant $(p<0.05$ ). More than half of the IE\&C group had low education, while more than half of the nonIE\&C group had no schooling. 
Table 1. Some characteristics of subjects

\begin{tabular}{|c|c|c|c|c|c|}
\hline \multirow[b]{2}{*}{$\begin{array}{l}\text { Background } \\
\text { Variables }\end{array}$} & \multicolumn{2}{|c|}{$\begin{array}{c}\text { Yes } \\
(\mathrm{N}=242)\end{array}$} & \multicolumn{2}{|c|}{$\begin{array}{c}\text { No } \\
(\mathrm{N}=536)\end{array}$} & \multirow[b]{2}{*}{$\mathrm{p}$} \\
\hline & $\mathbf{N}$ & $\%$ & $\mathrm{~N}$ & $\%$ & \\
\hline \multicolumn{6}{|l|}{ Education } \\
\hline No Schooling & 104 & 43.0 & 279 & 52.1 & \multirow[b]{3}{*}{0.0497} \\
\hline Low & 126 & 52.0 & 229 & 42.7 & \\
\hline High & 12 & 5.0 & 28 & 5.2 & \\
\hline \multicolumn{6}{|l|}{ Age (years) } \\
\hline $15-19$ & 28 & 11.6 & 45 & 8.4 & \multirow[b]{3}{*}{0.0424} \\
\hline $20-34$ & 182 & 75.2 & 384 & 71.6 & \\
\hline $35-49$ & 32 & 13.2 & 107 & 20.0 & \\
\hline \multicolumn{6}{|l|}{ Occupation } \\
\hline House-wife & 122 & 50.4 & 281 & 52.4 & \multirow{4}{*}{0.5498} \\
\hline Laborer & 39 & 16.1 & 67 & 12.5 & \\
\hline Farmer & 57 & 23.6 & 138 & 25.7 & \\
\hline Other & 24 & 9.9 & 50 & 9.3 & \\
\hline \multicolumn{6}{|l|}{ Marital Status } \\
\hline First marriage & 153 & 63.2 & 299 & 55.8 & \multirow{3}{*}{0.1257} \\
\hline Second marriage & 84 & 34.7 & 219 & 40.9 & \\
\hline Other & 5 & 2.1 & 18 & 3.4 & \\
\hline \multicolumn{6}{|l|}{ Contraceptive Use } \\
\hline Hormonal & 137 & 56.6 & 318 & 59.0 & \multirow{5}{*}{0.0815} \\
\hline IUD & 7 & 2.9 & 30 & 5.6 & \\
\hline Sterilization & 3 & 1.2 & 6 & 1.1 & \\
\hline None & 94 & 38.8 & 172 & 32.1 & \\
\hline Other & 1 & 0.4 & 12 & 2.2 & \\
\hline \multicolumn{6}{|c|}{ Number of living children } \\
\hline & 23 & 9.5 & 34 & 6.4 & \multirow[b]{3}{*}{0.0812} \\
\hline $1-2$ & 149 & 61.6 & 310 & 57.8 & \\
\hline 3 or more & 70 & 28.9 & 192 & 35.9 & \\
\hline
\end{tabular}

Age was divided into 3 categories, 15-19 years, 20-34 years, and 35-49 years. The IE\&C group tend to be younger. More than $85 \%$ of those in the IE\&C group were in the first 2 categories (15-34), compared to only $80 \%$ in the nonIE\&C group $(\mathrm{p}<0.05)$. More than half of the women in both groups were housewives, with $50.4 \%$ in the IE\&C group and $52.4 \%$ in the nonIE\&C group. About a quarter of the subjects were farmers. Except for 3 widows in the nonIE\&C group, all of the women were still married. In the IE\&C group, $63.2 \%$ were in their first marriage, with $55.8 \%$ in the nonIE\&C group.

Almost $60 \%$ of the women used modern contraceptives, with the majority using hormonal contraceptives, either in injectable form (DMPA) or orally (56.6\% and $59.0 \%)$.
Only a small number of the women have no living children, $9.5 \%$ in the IE\&C group and $6.4 \%$ in the nonIE\&C group. The majority have 1-2 living children $(61.6 \%$ and $57.8 \%)$.

\section{Perception of Breastfeeding}

In table 2 , it can be seen that $85.1 \%$ in the IE\&C group gave the right response to the first question, with only $18.3 \%$ in the nonIE\&C group. The incorrect response was $14.9 \%$ in the IE\&C group and $81.7 \%$ in the nonIE\&C group. The crude relative risk (RR) was 4.66 (95\% CI 3.86-5.61), which meant that women exposed to IE\&C were almost five times more likely to know the correct answer than those not exposed to IE\&C.

Table 2. Perception of breastfeeding, pre-lacteal and supplementary feeding

\begin{tabular}{|c|c|c|c|c|c|}
\hline \multirow{2}{*}{$\begin{array}{l}\text { Perception of hreast- } \\
\text { feeding, prelacteal } \\
\text { and supplementary } \\
\text { feeding }\end{array}$} & $\begin{array}{r}\text { resent } \\
\mathrm{Y} \\
(\mathrm{N}=\end{array}$ & IE \& & $\begin{array}{l}\text { on bre } \\
(\mathrm{N}\end{array}$ & feedin & \multirow{2}{*}{$\begin{array}{c}\text { RR } \\
\text { (Confidence } \\
\text { limits) }\end{array}$} \\
\hline & $\mathrm{N}$ & $\%$ & $\mathrm{~N}$ & $\%$ & \\
\hline $\begin{array}{l}\text { When to initiate breast- } \\
\text { feeding }\end{array}$ & & & & & $\begin{array}{l}4.66 \\
(3.86-5.61)\end{array}$ \\
\hline Immediately after birth & 206 & 85.1 & 98 & 18.3 & \\
\hline Other & 36 & 14.9 & 438 & 81.7 & \\
\hline $\begin{array}{l}\text { Colostrum is important } \\
\text { for the baby }\end{array}$ & & & & & $\begin{array}{c}1.53 \\
(1.44-1.64)\end{array}$ \\
\hline Yes & 238 & 98.3 & 344 & 64.2 & \\
\hline No & 4 & 1.7 & 192 & 35.8 & \\
\hline $\begin{array}{l}\text { Colostrum is harmful to } \\
\text { the bahy }\end{array}$ & & & & & $\begin{array}{c}0.03 \\
(0.01-0.11)\end{array}$ \\
\hline Yes & 3 & 1.2 & 191 & 35.6 & \\
\hline No & 239 & 98.8 & 345 & 64.4 & \\
\hline $\begin{array}{l}\text { Honey has to be given } \\
\text { before initiating breast- } \\
\text { feeding }\end{array}$ & & & & & $\begin{array}{c}0.07 \\
(0.04-0.12)\end{array}$ \\
\hline Yes & 11 & 4.5 & 367 & 68.5 & \\
\hline No & 231 & 95.5 & 169 & 31.5 & \\
\hline $\begin{array}{l}\text { When to start with } \\
\text { supplementary food }\end{array}$ & & & & & $\begin{array}{c}6.61 \\
(5.29-8.27)\end{array}$ \\
\hline Four months & 209 & 86.4 & 70 & 13.1 & \\
\hline Other & 33 & 13.6 & 466 & 86.9 & \\
\hline
\end{tabular}

The response to the second and third questions can be seen in table 2. Most of the women answered that the first flow of milk was important for the baby, $98.3 \%$ in the IE\&C group and $64.2 \%$ in the nonIE\&C group, with a crude RR of 1.53 (95\% CI 1.44-1.64). In the IE\&C group, $1.2 \%$ ( 3 women) and $35.6 \%$ in the 
nonIE\&C group answered that the first flow of milk is dangerous for the baby, with a crude RR of 0.03 (95\% CI 0.01-0.11). This mean that women exposed to IE\&C have a very low probability of saying that colostrum is harmful to the baby when compared to those that were not exposed to IE\&C.

Most of the women in the IE\&C group (95.5\%) responded correctly to the fourth question, compared to only $31.5 \%$ in the nonIE\&C group. The crude RR was 0.07 (95\% CI 0.04-0.12), which means that the women in the IE\&C group will be less likely to say that honey or syrup should be given to the baby prior to initiating breastfeeding.

It was found that $86 \%$ of the women in the IE\&C group said that supplementary food should be given at the age of four months compared to $13.1 \%$ in the nonIE\&C group, with a crude RR of 6.61 (95\% CI 5.29-8.27).

Both groups gave similar answers regarding the types of supplementary food suitable for the baby. The first option of bananas was chosen by $88.9 \%$ of the IE\&C group and $85.2 \%$ of the nonIE\&C group. The second option of soft steamed rice was chosen by $72.8 \%$ and $63.3 \%$ respectively, and the third option rice porridge, $11.5 \%$ and $11.9 \%$ respectively.

\section{Adjustments for age and education}

A stratified analysis was performed to adjust the relative risk (RR) to age and education separately. The results of the Mantel- Haenszel Relative Risk $\left(R_{R_{m h}}\right)$ or the adjusted rates are presented in table 3.

Table 3. Mantel-Haenszel weighted relative risk of woman given exposure to IE \& $\mathrm{C}$ (adjusted for age and education)

\begin{tabular}{ll}
\hline Perception & $\mathrm{RR}_{\mathrm{mh}}(95 \% \mathrm{CI})$ \\
\hline Adjusted for age & \\
A. When to initiate breastfeeding & $4.59(3.81-5.54)$ \\
B. Colostrum is important for the bady & $1.52(1.42-1.62)$ \\
$\begin{array}{l}\text { C. Colostrum is harmful to the baby } \\
\text { D. Honey has to be given before }\end{array}$ & $0.04(0.01-0.11)$ \\
$\quad$ initiating breastfeeding & $0.07(0.04-0.12)$ \\
E. When to start with supplementary food & $6.62(5.28-8.30)$ \\
& \\
Adjusted for education & \\
$\begin{array}{l}\text { A. When to initiate breastfeeding } \\
\text { B. Colostrum is important for the baby }\end{array}$ & $4.62(3.83-5.56)$ \\
C. Colostrum is harmful to the baby & $0.05(0.02-0.12)$ \\
D. Honey has to be given before & \\
$\quad$ initiating breastfeeding & $0.07(0.04-0.12)$ \\
E. When to start with supplementary food & $6.28(5.05-7.82)$ \\
\hline
\end{tabular}

\section{Adjustment for age}

The RR mh for the variable when you should start breastfeeding (question 1) was 4.59 (95\% CI 3.815.54). It did not differ greatly from the unadjusted rate of 4.66. The $R R_{m h}$ for the second question was 1.552 (95\% CI 1.42-1.62), while the unadjusted rate was 1.53. For the third question, the $\mathrm{RR}_{\mathrm{mh}}$ was 0.04 (95\% CI 0.01-0.11) with the unadjusted rate at 0.03 . The $\mathrm{RR}_{\mathrm{mh}}$ for the fourth question was 0.07 (95\% CI 0.04012 ), which was the same as the unadjusted rate of 0.07 . The $\mathrm{RR}_{\mathrm{mh}}$ for the fifth question was 6.62 (95\% CI 5.28-8.30), which was similar to the unadjusted rate of 6.61 .

\section{Adjustment for education}

The $R R_{m h}$ for the 5 questions were similar to the unadjusted rates. The adjusted rates $\left(\mathrm{RR}_{\mathrm{mh}}\right)$ for the 5 questions were: 4.62 (95\% CI 3.83-5.56) for question $1,1.52(95 \%$ CI $1.43-1.63)$ for question $2,0.05(95 \%$ CI $0.02-0.12$ ) for question $3,0.07$ (95\% CI 0.04-0.12) for question 4, and 6.28 (95\% CI 5.05-7.82) for question 5 .

\section{DISCUSSION}

It was found that women exposed to IE\&C were proportionally more likely to have the correct perception on breastfeeding, prelacteal, and supplementary feeding than unexposed women. This seemed to be attributed to exposure to the IE\&C program. In the last few years, breastfeeding has been promoted by the government as well as nongovermental organizations coordinated by the BK-PP-ASI, a national coordinating body on breastfeeding. ${ }^{7}$ It is important to seek simple and inexpensive ways of promoting breastfeeding. One way is through integration with the activities of various other sectors. In this way, discussion can be broaden to include other important topics, in addition to breastfeeding and family planning. It also makes use of available manpower. This study showed that promoting a program through integration with other activities can be effective in conveying information.

Since this study was not experimental in design, it was impossible to control factors that might influence the increase in the perception of breastfeeding. It was also impossible to determine whether IE\&C was the only source of information on breastfeeding or whether the information was limited only to the women attending the IE\&C sessions, because a substantial portion of the women in the nonIE\&C group possessed 
the right information on breastfeeding practice. The factors that influenced the women to attend or not attend the IE\&C sessions were also unknown.

Although the educational program was successful in conveying information on breastfeeding, it must be remembered that knowledge is only the beginning of a process of adopting new ideas. Evaluation should be continuous to assess retainment of information.

\section{Acknowledgements}

This study is a project of the Indonesian Epidemiological Network (JEN) supported by the University Research Corporation (URC). The author wishes to thank Dr. Budi Utomo, the Director of the Center for Health Research of the University of Indonesia, for his support and encouragement, Miss Sudarti, the principal investigator for the Study on Breastfeeding and Family Planning in the Subdistrict of Gabus Wetan, Indramayu, for her support, Mr. Yusran Nasution, who assisted in data analysis.

\section{REFERENCES}

1. World Health Organization, Breast-feeding and child spacing, What health workers need to know, Programme on Maternal Child Health and Family Planning, Geneva, 1988.

2. Riduan JM, Annest JL, Utomo B. A Recent Increase of Breastfeeding Duration in Jakarta, Indonesia, Am J Public Health 1988, 79(1):36-8.

3. Iskandar MB, C. Costello C, Y. Nasution. Initiation and Duration of Breastfeeding in Indonesia, Asia Pac Popul J 1990 March, 5(1):89-112.

4. Indonesian Epidemiology Network, Complementing Family Planning with Breastfeeding to Improve Child and Maternal Health: A Comparative Study of A Rural and An Urban Slum Population of Indonesia, JEN, 1989.

5. Indonesian Epidemiology Network, Report on Implementation of Intervention, Complementing Family Planning with Breastfeeding to Improve Child and Maternal Health, JEN (undated).

6. Utomo B. et al. Studi ASI dan Keluarga Berencana di Kecamatan Gabuswetan Kabupaten Indramayu, Laporan Sementara, JEN, 1991.

7. Suyono H, Thapa S. Breast-feeding and the Family Planning Sector's Initiative in Indonesia, Asia Pac Popul J 1990 March, 5 (1):151-6. 